\title{
Auto-/homografting can work well even if both autograft and allograft are meshed in 4:1 ratio
}

\author{
İsmail Şahin, M.D., Doğan Alhan, M.D., Mustafa Nışancı, M.D., \\ Fırat Özer, M.D., Muhitdin Eski, M.D., Selçuk Işık, M.D. \\ Department of Plastic and Reconstructive Surgery, Gulhane Military Medical Academy, Ankara
}

\begin{abstract}
BACKGROUND: Patients suffering major burns of more than $50 \%$ total burn surface area lack an adequate skin graft donor site to resurface extensive burn wounds and usually need widely meshed autografting and allografting. Anything over the 3:I expansion ratio is strongly associated with low graft take, poor or delayed epithelialization, and hypertrophic scarring.

METHODS: In this study, both autografts and allografts were expanded at a 4:I ratio. We aimed to use skin grafts effectively and to decrease the morbidity due to graft harvesting. Nine patients with major burns were treated with this method. Graft gain ratio and percentage of actual expansion to predicted expansion were calculated.

RESULTS: Ten auto-allografting procedures were performed on a mean of day 16. Graft take was over $95 \%$ successful. Five patients survived, and four patients died. The mean total burn surface area was $58.8 \%$ in patients who recovered, and $77.5 \%$ in the patients who died. The graft gain ratio was $74.8 \%$. The actual expansion rate was $43.7 \%$ of the predicted expansion rate.
\end{abstract}

CONCLUSION: In this study, we demonstrated that the donor site morbidities were reduced and successful epithelialization was completed on the eighth day after using both autograft and allograft meshed with a $4: 1$ ratio.

Key words: Allograft; autograft; graft expansion; major burn.

\section{INTRODUCTION}

Early excision of deep burn wounds has been one of the most critical advances in modern burn care. Janzekovic ${ }^{[1]}$ emphasized the advantages of early burn wound excision and closure, and it is generally accepted that this technique is a life-saving procedure. Split thickness skin autografting is the gold standard surgical treatment for coverage of deep partial and full-thickness burn wounds. Autografting has very important functions including epidermal function and prevention of infection, protein loss, and hypothermia. ${ }^{[2]}$ However, coverage of the wounds of patients with major burns is commonly limited by the lack of available skin graft donor sites. ${ }^{[2-5]}$

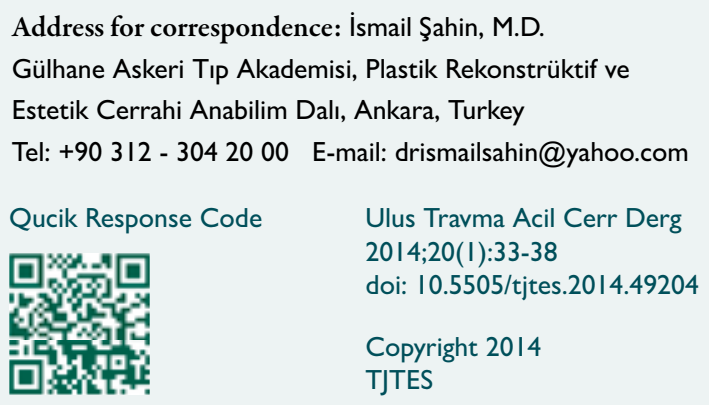

Several autogeneic or allogeneic materials (human allografts, xenografts, human amnions, allogeneic cultured dermal substitute, cultured epithelial autograft) or techniques (meshed auto-allografting with various ratios, widely meshed auto-skin with allogeneic cultured dermal substitute, microskin autografting, etc.) are used clinically to overcome this problem..$^{[5-8]}$ Although each technique has its own advantages, they also have many disadvantages, including low graft take, high cost, infectious diseases, and delay or poor epithelialization.

Skin graft meshing as described by Lanz ${ }^{[9,10]}$ has many advantages, including increasing the graft area, improving graft take rates by preventing seroma and hematoma, and better graft take over the irregular contoured surfaces. However, the question remains as to the optimal skin graft meshing ratio. Meshed autografts with a 3:I ratio have been recommended in the literature because 6:I and greater expanded grafts are often accompanied by significant graft loss and poor epithelialization. ${ }^{[5]}$ Allografts with I.5:I or 2:I meshed ratio over the autografts provide epithelialization between the inter-space of autograft bridges.

When skin is meshed, the increase in skin area will not be sufficient to multiply harvested skin with a ratio of expansion. Peeters and Hubens ${ }^{[I I]}$ measured the expansion area of the 
skin grafts with I.5:I and 3:I ratios before and after grafting, and they found skin graft expansions of only $82 \%$ and $50 \%$ of the expected amount for each ratio, respectively. It is important to know before the operation how much skin area can be gained after meshing, as this will inform physicians how much burned area can be covered in one session, and will decrease the morbidity due to allograft harvest.

In this clinical study, we aimed to present the results of nine major burn patients whose burn wounds were treated in our burn center with skin autograft and allograft, both meshed at a $4: 1$ ratio.

\section{MATERIALS AND METHODS}

Nine patients treated with auto-allografting due to major burns between 2008 and 2011 were included in the study. The Lund and Browder chart was used to calculate the size of the burn injury. Allograft donors were close relatives, and specific preoperative screening tests for human immunodeficiency virus (HIV) and hepatitis were conducted for all allograft donors.

All operations were performed under general anesthesia. First, split-thickness skin allografts were harvested from the thigh in all allograft donors with the aid of an electrical dermatome $\left(\right.$ Padgett $\left.^{\circledR}\right)$ set at 0.012 inch. Immediately after the harvesting of the allograft, the size of the donor area was measured and recorded as a pre-expanded allograft area (Fig. Ia). Autografts were harvested from any suitable area of the patients (thigh, abdominal area, scalp, leg). The size of the donor area was measured and recorded as a pre-expanded autograft area. Both autografts and allografts were meshed with Padgett ${ }^{\circledR}$ Skin Graft Mesher in a 4:I ratio (Fig. Ib). After tangential excision of the necrotic and eschar tissue, autografts were placed on the burn wound area. One edge of the graft was sutured using a skin stapler, and the graft was expanded vertically until the angle between graft bridges was $90^{\circ}$ (Fig. 2). The meshed
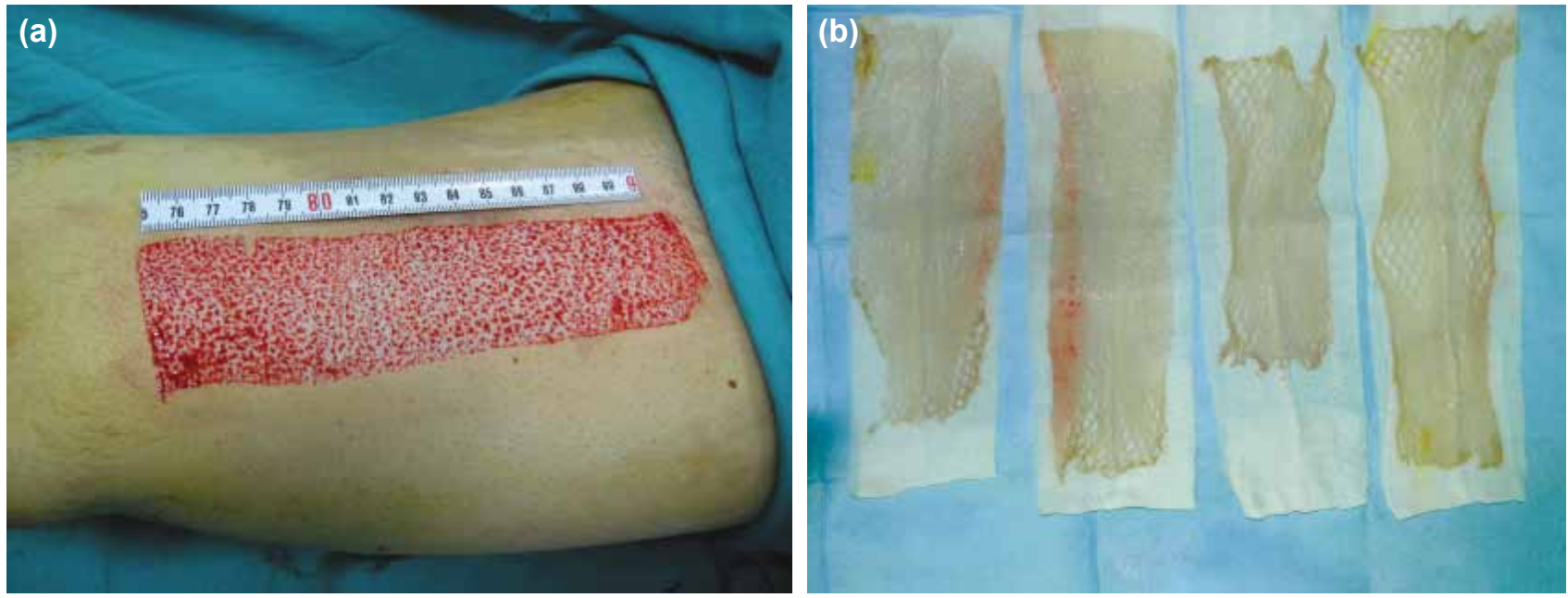

Figure 1. (a) The graft donor area was measured immediately after the graft harvesting. (b) Allografts meshed with 4:1 ratio.
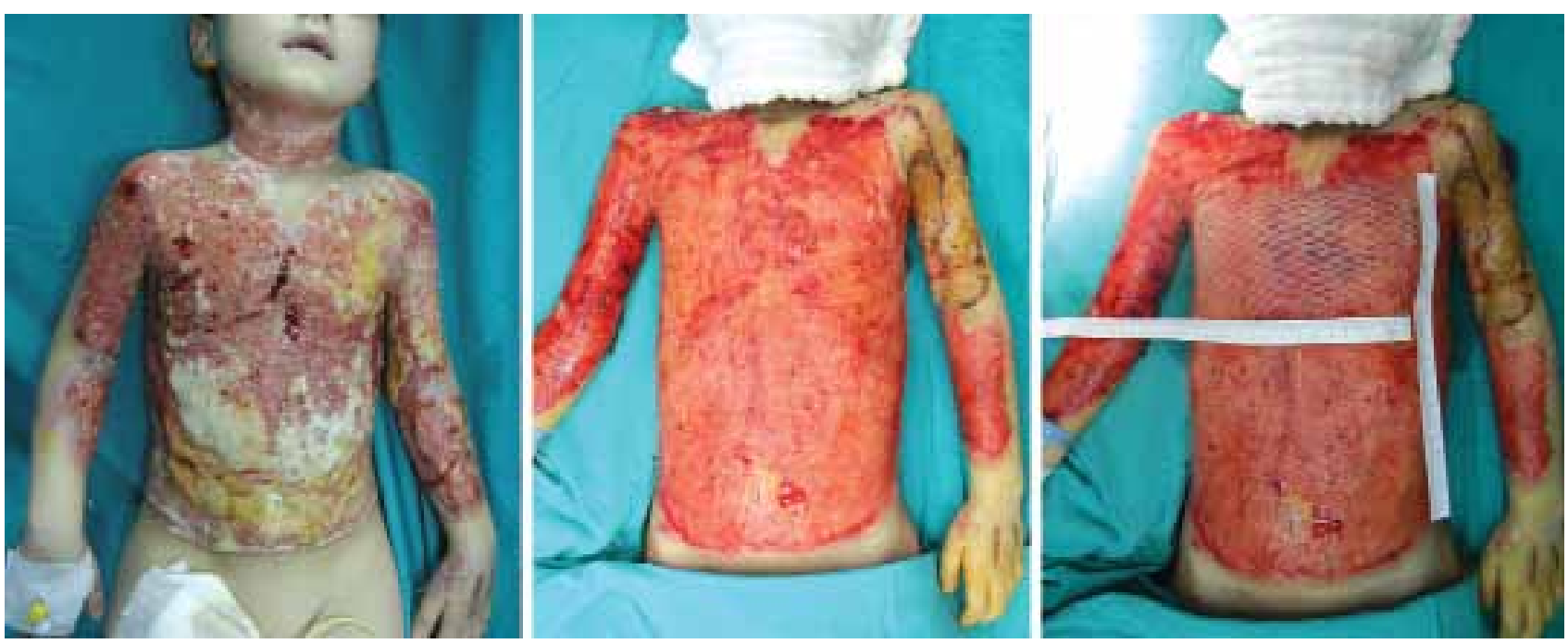

Figure 2. Preoperative appearance of the patient (left); after tangential excision of the necrotic and eschar tissue (middle), autografts were placed on the burn wound area. 


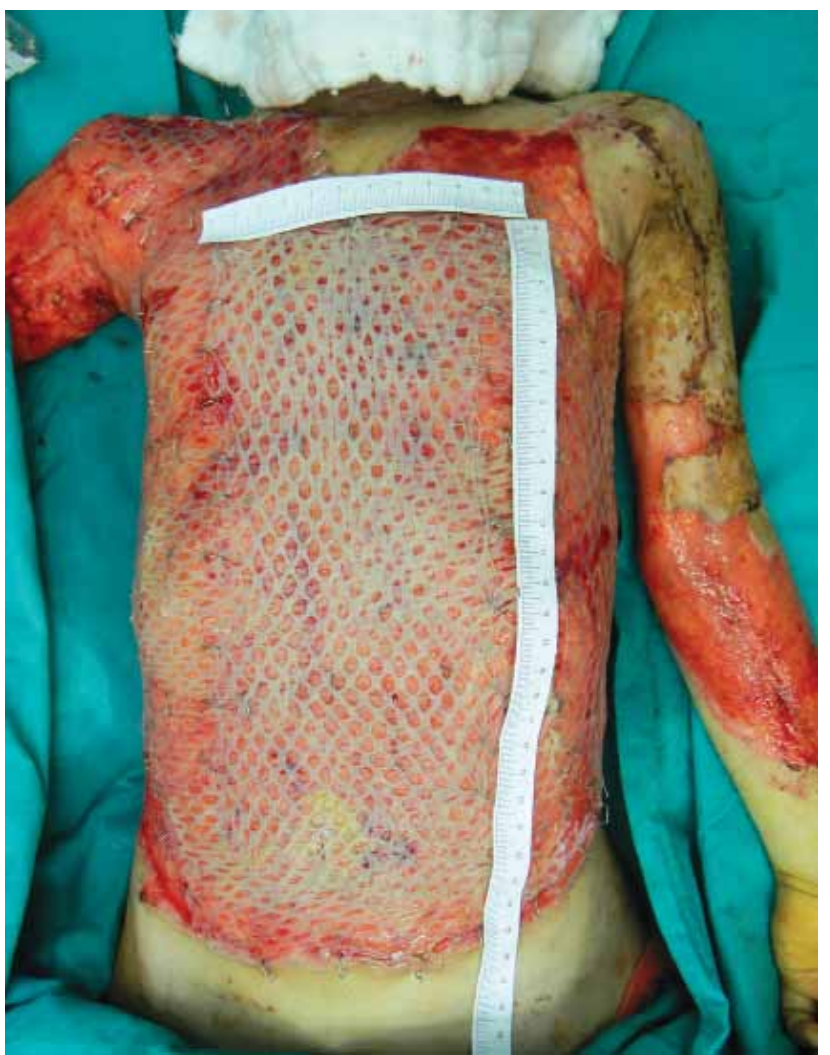

Figure 3. Allografts were placed over the autograft in the same manner.

graft area was measured and recorded as an expanded autograft area. Allografts were placed over the autograft in the same manner, and the meshed allograft area was measured and recorded as an expanded allograft area (Fig. 3). Autoallografts were covered with Bactigras ${ }^{\circledR}$, and the first dressing change was made on the postoperative 3rd day. After the first dressing change, graft care was performed on a daily basis to monitor autograft take and allograft rejection.

\section{RESULTS}

Demographic characteristics of the patients are presented in
Table I. Five patients survived, and four patients died. Of the nine patients, six were male and three were female, with a mean age of 26.3 years (range, 6-50). The mean age of the exitus and surviving patients was 28 years (range, $21-48$ ) and 25 years (range, 6-50), respectively. The total body surface area (TBSA) of these nine patients ranged between $42 \%$ and $87 \%$. The mean TBSA of the exitus and surviving patients was 77.5 (range, 70-85) and 58.8 (range, 42-87), respectively (Fig. 4).

We performed 10 auto-allografting procedures (twice in I patient) at an average of 16 days (range, 3-35). The mean pre-expanded and expanded autograft area was $81.88 \mathrm{~cm}^{2}$ (range, $48-160 \mathrm{~cm}^{2}$ ) and $143.77 \mathrm{~cm}^{2}$ (range, $90-280 \mathrm{~cm}^{2}$ ), respectively. The mean pre-expanded and expanded allograft donor area was $68.55 \mathrm{~cm}^{2}$ (range, $36-91 \mathrm{~cm}^{2}$ ) and $121.33 \mathrm{~cm}^{2}$ (range, 63-165 cm $\mathrm{cm}^{2}$ ), respectively. Skin grafts were expanded to $74.8 \%$ of the expected expansion. The actual expansion area at this ratio was $43.7 \%$ of the expected expansion.

Graft take percentage was over 95\%, and epithelialization between graft bridges was achieved on approximately the postoperative 8th day (Fig. 5). No secondary operations were needed. An average of $15.2 \%$ of the BSA was grafted in one procedure. We did not observe any clinically significant allograft rejection.

\section{DISCUSSION}

In this study, autografts and allograft meshed with a $4: 1$ ratio were used for closure of major burn wounds. We found that the wounds could be closed successfully with epithelialization on the 8th day. Skin grafts were expanded to $74.8 \%$ of expected, and the actual expansion area at this ratio was $43.7 \%$ of expected.

Richard et al. ${ }^{[12]}$ compared two different skin mesher systems for maximal skin graft expansion, and they found skin graft expansion was $65.7 \%$ of expected for a $2: 1$ meshing ratio and $41.4 \%$ of expected for a $4: 1$ meshing ratio, similar to our re-

Table I. The demographic characteristics of the patients

\begin{tabular}{|c|c|c|c|c|c|c|c|}
\hline Patient no & Age/Sex & TBSA & Etiology & Donor & $\begin{array}{l}\text { Time of the } \\
\text { initial surgery }\end{array}$ & $\begin{array}{l}\text { Length of hospital } \\
\text { stay (day) }\end{array}$ & Result \\
\hline I & $31 / M$ & 53 & Flame & Father & 21 & 40 & Survived \\
\hline 2 & $48 / F$ & 70 & Flame+inhalation & Boy & 3 & 56 & Death \\
\hline 3 & $30 / M$ & 42 & Electric & Father & 24 & 180 & Survived \\
\hline 4 & $8 / F$ & 62 & Flame & Mother & 5 & 50 & Survived \\
\hline 5 & $6 / F$ & 50 & Scald & Mother & 24 & 105 & Survived \\
\hline 6 & $50 / M$ & 87 & Flame+inhalation & Boy, brother & 18,35 & 150 & Survived \\
\hline 7 & $21 / M$ & 84 & Flame+inhalation & Father & 18 & 34 & Death \\
\hline 8 & $21 / M$ & 71 & Flame+inhalation & Father & 17 & 27 & Death \\
\hline 9 & $22 / M$ & 85 & Flame+inhalation & Brother & 15 & 42 & Death \\
\hline
\end{tabular}



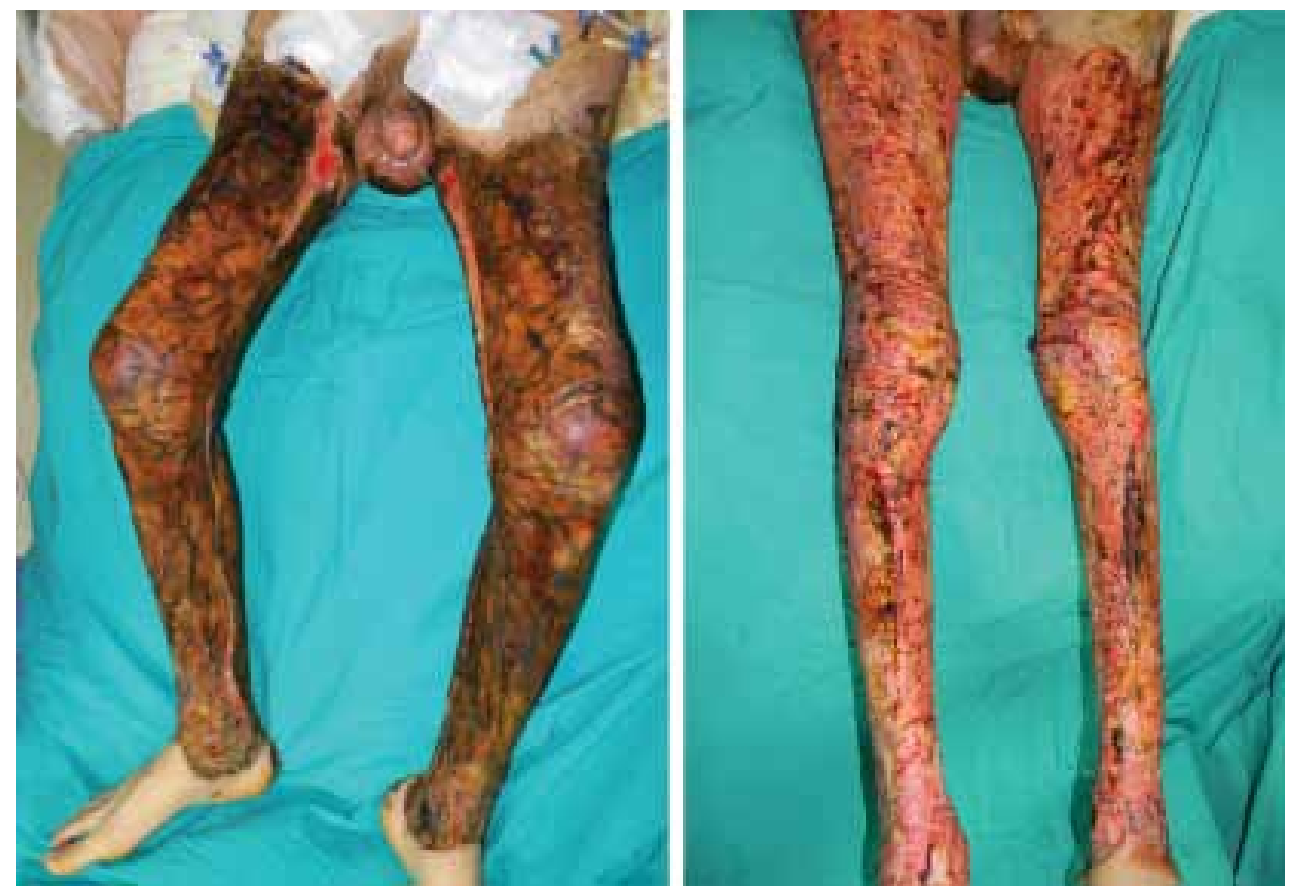

Figure 4. Appearance of the patient on the postoperative 8th day. The epithelialization between graft bridges was achieved.

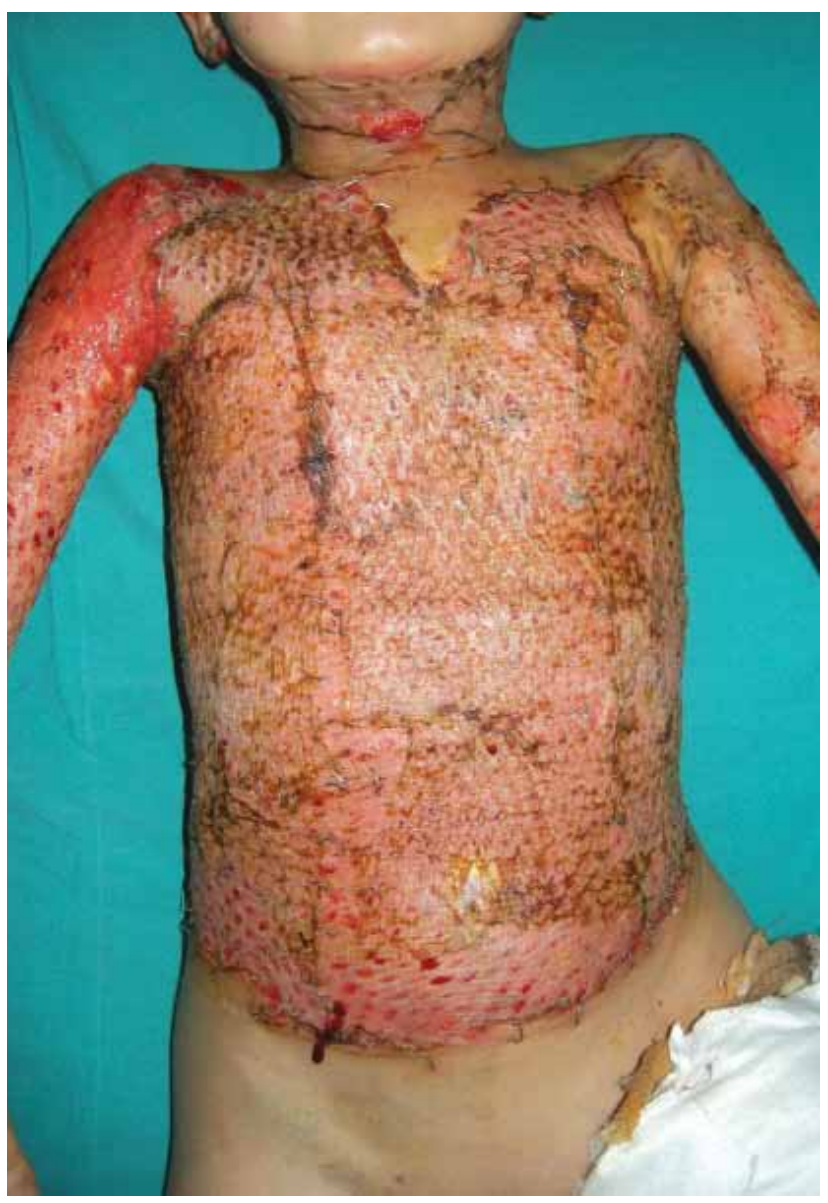

Figure $5.84 \%$ flame+inhalation burn. The patient died on the postburn 34th day with intact auto-allograft (appearance of the autoallografts on the postoperative 10th day). sults. However, we believe that both our results and their results are subjective because of non-standardized stretching of the graft. With a standardized stretching method, more predictable results could be obtained.

The data obtained from this study have several clinically important advantages. To the best of our knowledge, this is the first time that allograft over autograft meshed with a $4:$ I ratio for closure of burn wounds has been presented in the literature, and we showed that successful epithelialization could be achieved on the wound with this expansion ratio of the grafts.

Closure of large burn areas in one session is one of the most important goals in the treatment of major burns because patients with major burns may not survive long enough to undergo an additional skin grafting operation. Therefore, autografts obtained from a limited donor area should be used as effectively as possible. Autografts with a 3:I expansion ratio and fresh allograft with a 2:I expansion ratio are still recommended. ${ }^{[5]}$ There are many articles describing skin graft expansion ratios from $1.5: 1$ to $1: 30 .^{[13-15]}$ However, anything over the 3:I expansion ratio is strongly associated with low graft take, poor or delayed epithelialization, and hypertrophic scarring. To overcome these problems, many autogeneic or allogeneic materials have been tested.

Kashiwa et al. ${ }^{[5]}$ used concomitant grafting of six-fold extended mesh auto-skin and allogeneic cultured dermal substitute (CDS) for the treatment of full-thickness skin defect. CDS was applied repeatedly at intervals of 3-5 days. The mean 
number of CDS exchanges was 7 , and most of the wound surface between the strips of meshed skin epithelialized within three weeks. Cultured keratinocytes were first used as permanent autografts in burn wounds, but the results remain controversial. Many centers have stopped using the method because of low take and high cost. ${ }^{[16,17]}$

In a recent article, Chen et al. ${ }^{[8]}$ used microskin autografting to cover burn wounds with autografts expanded from a $1: 6$ to $\mathrm{I}:$ I 8 ratio. Briefly, autografts were cut into tiny pieces smaller than I mm. ${ }^{[3]}$ Micrografts were applied to the wound and covered with a large sheet of allograft. Forty of 63 patients with burn size over $70 \%$ survived with this technique. In this excellent study, microskin autografting failed to take in eight patients because the allograft did not take in the first postoperative dressing change. The authors stated that a large sheet of viable allograft skin is necessary and should first be guaranteed to obtain a successful take of the microskin autograft. Therefore, this technique could not be applied theoretically in countries like ours, which do not have a skin bank facility.

With the described method, we can determine how much allograft is needed, so that it is possible to prevent donor site morbidities, or we can harvest the allografts more precisely. Richard et al. ${ }^{[12]}$ found that when meshed skin grafts are used for wound closure, $12.9 \%-58.6 \%$ greater than the anticipated area of donor skin should be harvested. Both autografts and allografts were used efficiently and the donor site morbidities were reduced with the $4: 1$ expansion rate. With this technique, we were able to close $15.2 \%$ of TBSA in one procedure.

There is no skin bank in our country. In the countries in which there are skin banks and cadaver skin can be used, the amount of allograft needed to close the burn wound can be determined preoperatively. Thus, the use of unnecessary allograft and cost can be prevented. Horner et al. ${ }^{[18]}$ examined the records of patients that were treated with allograft in the burn center. They calculated the amount of allograft and termed it as an allograft index. They thusly calculated the amount of allograft that the skin bank was required to have for fire disaster and ordinary usage.

In this study, five patients survived, and the four patients that died all had inhalation injury. Muller et al. ${ }^{[19]}$ evaluated the charts of 4094 patients retrospectively. Multivariate analysis of the individual prognostic factors showed that the determinants of death were increasing age and burn size, inhalation injury, and female sex. Ryan et al. ${ }^{[20]}$ conducted a similar retrospective review of 1665 patients. They found that identifiable risk factors for death were an age greater than 60 years, a burn covering more than $40 \%$ TBSA, and inhalation injury. They stated that patient mortality is $0.3 \%$ with no risk factors, $3 \%$ with one risk factor, $33 \%$ with two risk factors, and approximately $90 \%$ with all three risk factors.
In conclusion, patients with greater than 50\% TBSA may have limited skin graft donor area for covering burn wounds. We believe that auto-allografting is the gold standard treatment modality in these patients. It is crucial to find the most effective skin expansion rate and to determine how much skin is required for covering. In our study, we aimed to answer these questions. We used both autograft and allograft with a $4: 1$ expansion rate and were able to cover extensive burn wound areas successfully in two weeks without requiring a secondary intervention.

Conflict of interest: None declared.

\section{REFERENCES}

1. Janzekovic Z. A new concept in the early excision and immediate grafting of burns. J Trauma 1970;10:1103-8. CrossRef

2. Coruh A, Yontar Y. Application of split-thickness dermal grafts in deep partial- and full-thickness burns: a new source of auto-skin grafting. J Burn Care Res 2012;33:94-100. CrossRef

3. Alexander JW, MacMillan BG, Law E, Kittur DS. Treatment of severe burns with widely meshed skin autograft and meshed skin allograft overlay. J Trauma 1981;21:433-8.

4. Qaryoute S, Mirdad I, Hamail AA. Usage of autograft and allograft skin in treatment of burns in children. Burns 2001;27:599-602. CrossRef

5. Kashiwa N, Ito O, Ueda T, Kubo K, Matsui H, Kuroyanagi Y. Treatment of full-thickness skin defect with concomitant grafting of 6-fold extended mesh auto-skin and allogeneic cultured dermal substitute. Artif Organs 2004;28:444-50. CrossRef

6. Ramakrishnan KM, Jayaraman V. Management of partial-thickness burn wounds by amniotic membrane: a cost-effective treatment in developing countries. Burns 1997;23 Suppl 1:33-6. CrossRef

7. Ersek RA, Denton DR. Silver-impregnated porcine xenografts for treatment of meshed autografts. Ann Plast Surg 1984;13:482-7. CrossRef

8. Chen XL, Liang X, Sun L, Wang F, Liu S, Wang YJ. Microskin autografting in the treatment of burns over $70 \%$ of total body surface area: 14 years of clinical experience. Burns 2011;37:973-80. CrossRef

9. Haeseker B. Forerunners of mesh grafting machines. From cupping glasses and scarificators to modern mesh graft instruments. Br J Plast Surg 1988;41:209-12. CrossRef

10. Henderson J, Arya R, Gillespie P. Skin graft meshing, over-meshing and cross-meshing. Int J Surg 2012;10:547-50. CrossRef

11. Peeters R, Hubens A. The mesh skin graft--true expansion rate. Burns Incl Therm Inj 1988;14:239-40. CrossRef

12. Richard R, Miller SF, Steinlage R, Finley RK Jr. A comparison of the Tanner and Bioplasty skin mesher systems for maximal skin graft expansion. J Burn Care Rehabil 1993;14:690-5. CrossRef

13. Dziewulski P, Phipps AR. Modification of the dermacarrier to obtain meshed split skin grafts of different expansion ratios. Br J Plast Surg 1991;44:315-7. CrossRef

14. Nanchahal J. Stretching skin to the limit: a novel technique for split skin graft expansion. Br J Plast Surg 1989;42:88-91. CrossRef

15. Blair SD, Nanchahal J, Backhouse CM, Harper R, McCollum CN. Microscopic split-skin grafts: a new technique for 30-fold expansion. Lancet 1987;2:483-4. CrossRef

16. Grafting of burns with cultured epithelium prepared from autologous epidermal cells. Lancet 1981;1:75-8. 
17. Lineen E, Namias N. Biologic dressing in burns. J Craniofac Surg 2008;19:923-8. CrossRef

18. Horner CW, Atkins J, Simpson L, Philp B, Shelley O, Dziewulski P. Estimating the usage of allograft in the treatment of major burns. Burns 2011;37:590-3. CrossRef
19. Muller MJ, Pegg SP, Rule MR. Determinants of death following burn injury. Br J Surg 2001;88:583-7. CrossRef

20. Ryan CM, Schoenfeld DA, Thorpe WP, Sheridan RL, Cassem EH, Tompkins RG. Objective estimates of the probability of death from burn injuries. N Engl J Med 1998;338:362-6. CrossRef

\section{KLINIK ÇALIŞMA - ÖZET}

\section{Hem otogreft hem de allogreft 4:1 oranında meşlendiğinde bile otohomogreftleme başarılı olabilir}

\section{Dr. İsmail Şahin, Dr. Doğan Alhan, Dr. Mustafa Nışancı, Dr. Fırat Özer, Dr. Muhitdin Eski, Dr. Selçuk Işık}

Gülhane Askeri Tıp Akademisi, Plastik Rekonstrüktif ve Estetik Cerrahi Anabilim Dalı, Ankara

AMAÇ: Vücut yüzey alanının \%50'sinden fazlasının yandığı majör yanıklı hastalarda geniş yanık alanlarının tedavisinde deri grefti donör alanları yetersiz kalır ve bu hastalar genellikle genişçe meşlenmiş otogreftleme ve allogreftlemeye ihtiyaç duyarlar. 3: I'in üzerindeki meşleme oranları kuvvetle az greft tutması, kötü veya gecikmiş epitelizasyon ve hipertrofik skar ile beraberlik gösterir.

GEREÇ VE YÖNTEM: Bu çalışmada otogreftler ve allogreftler 4:I oranında meşlendi. Deri greftlerini daha efektif kullanmayı ve greft alınmasına bağlı morbiditeyi azaltmayı amaçladık. Majör yanıklı 9 hasta bu yöntemle tedavi edildi. Greft kazanç oranları ve gerçek greft genişleme oranının beklenen genişleme oranına olan yüzdesi hesaplandı.

BULGULAR: Ortalama 16. günde ve toplam 10 oto-allogreftleme ameliyatı gerçekleştirildi. Greft tutma oranı \%95 idi. Beş hasta yaşamaya devam ederken 4 hasta çalışma esnasında hayatını kaybetti. Yaşayan hastalarda ortalama toplam vücut yanık alan yüzdesi \%58.8 iken ölen hastalarda bu oran \%77.5 idi. Greft kazanç oranı \%74.8 oldu. Gerçek greft genişleme oranı beklenenin \%43.7'si olarak bulundu.

TARTIŞMA: Bu çalışmada, otogreftler ve allogreftler 4:I oranında meşlendiğinde, donör alan morbiditesinin azaltıldığı ve 8. günde başarılı epitelizasyonun sağlandığı gösterilmiştir.

Anahtar sözcükler: Allogreft; greft genişlemesi; majör yanık; otogreft.

Ulus Travma Acil Cerr Derg 20 14;20(I):33-38 doi: 10.5505/tjtes.20।4.49204 